\title{
SKRINING SENYAWA METABOLIT SEKUNDER KARANG LUNAK (Sarcophyton sp.) SEBAGAI ANTI BAKTERI DARI PERAIRAN TANJUNG TIRAM
}

\section{Screening and Identification Metabolites Secondary of Soft Coral (Sarcophyton sp.) as Antibacterial from Tanjung Tiram Waters}

\author{
Olga Galih $^{1}$, Baru Sadarun ${ }^{2}$, Sahidin $^{3}$ \\ ${ }^{1}$ Mahasiswa Jurusan Ilmu Kelautan, \\ Fakultas Perikanan dan Ilmu Kelautan, Universitas Halu Oleo. \\ Jl. H.E.A Mokodompit Kampus Hijau Bumi Tridharma Anduonohu Kendari 93232, Telp/Fax: (0401) 3193782 \\ ${ }^{2}$ Surel: sadarunbaru@gmail.com \\ ${ }^{3}$ Surel: sahidin02@yahoo.com
}

\begin{abstract}
Abstrak
Sarcophyton sp.yang merupakan biota karang lunak dari Phylum Coelenterata (Cnidaria) golongan Octocoralia yang mampu mendominasi di wilayah terumbu karang salah satunya di peraian Tanjung Tiram, potensi senyawa bioaktif pada Sarcophyton sp. sangatlah bermanfaat baik di bidang farmasi, ataupun kedokteran sebagai sumber obat alami. Penelitian ini bertujuan untuk mengetahui golongan senyawa metabolit apa yang terkandungan Sarcophyton sp. dan membandingkan daya hambat aktifitas anti bakteri terhadap bakteri Staphylococcus aureus dan Escherichia coli pada ekstrak dan fraksi partisi dengan tingkat kepolaran yang berbeda yaitu pada ekstrak n-heksan, etil-asetat serta methanol. Metode yan digunakan meliputi ekstraksi, partisi, uji skrining fitokimia dan difusi agar untuk mengevaluasi antibakteri. Hasil dari penelitian ini menemukan teridentifikasi 3 macam senyawa bioaktif yakni alkaloid, steroid/terpenoid, Flavanoid/venolik. Ekatrak dan fraksi Sarcophyton sp. yang paling tinggi kandungan metabolit sekundernya yaitu pada ektrak etil-asetat dan ektrak n-heksan dari karang lunak Sarcophyton sp. dengan nilai RF 1 untuk steroid/terpenoid, RF 0,96 untuk fenolik/ flafanoid, dan 0,9625 untuk alkaloid. Aktivitas daya hambat ektrak n-heksan berpotensi sebagai antibakteri aktif terhadap bakteri $S$. aureus pada konsentrasi $1000 \mathrm{ppm}$ dengan diameter zona hambat sebesar 14,5 mm. Aktivitas daya hambat ektrak metanol dari karang lunak Sarcophyton sp. berpotensi sebagai antibakteri aktif terhadap bakteri E. coli pada konsentrasi 500 ppm dengan nilai diameter zona hambat sebesar 13,3 $\mathrm{mm}$.
\end{abstract}

Kata Kunci: Antibakteri, Metabolit Sekunder, Sarcophyton sp., Skrining.

\begin{abstract}
Research on screening of secondary metabolites from Sarcophyton sp. as an anti bacterial from the waters of Tanjung Tiram it has been done This study aims to determine what groups of metabolites contain Sarcophyton sp. and comparing the inhibitory strength of anti-bacterial activity against Staphylococcus aureus and Escherichia coli bacteria in extracts and partition fractions with different levels of polarity, namely n-hexane, ethyl-acetate and methanol extract. The methods used include extraction, partitioning, phytochemical screening tests and agar diffusion to evaluate antibacterial. The results of this study found three types of bioactive compounds identified as alkaloids, steroids / terpenoids, flavanoids / venicides. Ekatrak and the fraction of Sarcophyton sp. the highest content of secondary metabolites is the extract of ethyl-acetate and n-hexane extract from Sarcophyton sp. soft coral. with RF 1 values for steroids / terpenoids, RF 0.96 for phenolic / flafanoids, and 0.9625 for alkaloids. The inhibitory activity of n-hexane extract has the potential as an active antibacterial against $\mathrm{S}$. aureus at a concentration of $1000 \mathrm{ppm}$ with a diameter of the inhibition zone of 14.5 $\mathrm{mm}$. The inhibitory activity of methanol extract from Sarcophyton sp. Soft coral. has the potential as an active antibacterial against E. coli bacteria at a concentration of $500 \mathrm{ppm}$ with a diameter inhibition zone of $13.3 \mathrm{~mm}$.
\end{abstract}

Keywords: Antibacterial, Secondary Metabolites, Sarcophyton sp., Screening,

\section{Pendahuluan}

Biota laut merupakan sumber bahan alam yang sangat kaya dengan aktifitas biologinya, salah satunya yaitu Sarcophyton sp yang merupakan biota karang lunak dari Phylum Coelenterata (Cnidaria), golongan Octocoralia yang mampu mendominasi di wilayah terumbu karang perairan pasifik (Sammarco, 1992).
Potensi senyawa bioaktif pada Sarcophyton sp sangatlah bermanfaat baik di bidang farmasi, ataupun kedokteran sebagai sumber obat alami. Hasil penelitian yang dilakukan Badria et al. (1998) dan Swant et al. (2006) menunjukkan bahwa, senyawa kimia aktif yang terdapat pada karang lunak Sarcophyton sp menunjukkan aktivitas sebagai 
antibakteri, antifungi, antitumor, neurotoksik, dan anti-inflamantori.

Perairan Tanjung Tiram merupakan salah satu perairan yang memiliki ekosistem terumbu karang yang cukup bagus dan memiiki berbagai macan jenis organisme yang melimpah, salah satunya syaitu karang lunak dengan jenis Sarcophyton sp. Karang lunak tersebut dapat di jumpai pada kedalaman kisaran 1 hingga 10 meter.

Adanya Sarcophyton sp pada perairan Tanjung Tiram dengan potensi kandungan senyawa metabolit sekunder, menjadi pertimbangan untuk dilakukannya penelitian tentang skrining senyawa metabolit sekunder Sarcophyton sp sebagai antibakteri dari perairan Tanjung Tiram, Kabupaten Konawe Selatan.

Karang lunak Sarcophyton sp merupakan salah satu avertebrata laut yang memiliki potensi sebagai bahan bioaktif. Rumusan masalah dalam penelitian ini yaitu: (1) Golongan senyawa metabolit apakah yang terkandungan Sarcophyton sp. ?; (2) Ekstrak dan fraksi partisi (N-Hexan, Etil-asetat dan Metanol) manakah yang lebih tinggi kandungan metabolit sekunder dari ketiga fraksi (N-Hexan, Etil-asetat dan Metanol) dari metode yang digunakan dalam maserasi bertingkat pada Sarcophyton sp. ? (3) Bagaimana aktifitas daya hambat metabolit sekunder terhadap bakteri Staphylococcus aureus dan Escherichia coli ?

Tujuan dari penelitian ini yaitu untuk mengetahui golongan senyawa metabolit apa yang terkandungan Sarcophyton sp. Mengetahui fraksi (N-Hexan, Etil-asetat dan Metanol) mana yang lebih tinggi kandungan metabolit sekunder dari ketiga fraksi (N-Hexan, Etil-asetat dan Metanol) dari metode yang digunakan dalam maserasi bertingkat pada Sarcophyton sp. Mengetahui aktifitas daya hambat metabolit sekunder tiap fraksi terhadap bakteri Staphylococcus aureus dan Escherichia coli.

\section{Bahan dan Metode}

Penelitian ini akan dilakukan melalui dua tahapan yakni pengambilan data lapangan dan analisis sampel. Pengambilan data lapangan dilaksanakan pada Juni hingga Agustus 2018, bertempat di Perairan Tanjung Tiram Kecamatan Moramo Utara, Kabupaten Konawe Selatan Sulawesi Tenggara. Analisis sampel dilakukan di Laboratorium Farmasi Jurusan Farmasi Fakultas Farmasi Universitas Halu Oleo, Kendari.
Alat dan bahan yang digunakan pada penelitian meliputi peralatan lapangan seperti Handrefractometer, GPS, Layangan Arus, Alat Scuba Diving, Underwater Camera, Thermometer, Secchi Disk, Plastik Sampel, Palu dan Tatah, plastik sampel dan Cool box. Peralatan Laboratorium seperti gelas ukur, gelas piala, jarum ose, pipet skala,capet, hot plate, botol semprot, corong, laminar airflow, pipet tetes, oven, evaporator,lampu spirtus, pipa kapiler, mistar, autoclave, inkubator, kuvet, rak tabung, tabung reaksi, lampu UV 366 dan UV 254.

Bahan penelitian berupa karang lunak Sarchopyton sp. Alkohol 70\%, Methanol, Asam sulfat 2N, Asam sulfat pekat, Kloroform, Plat KLT, Nutrient Agar (NA), Reagen dragendrof, Pereaksi liebermann-bucard, $\mathrm{FeCl} 31 \%$, Kloramfenikol, bakteri E. Coli dan bakteri $S$. Aureus.

Metode lapangan yang dilakukan meliputi survey pendahuluan, penentuan stasiun penelitian, pengambilan sampel karang lunak Sarcophyton $\mathrm{sp}$ dan pengukuran parameter lingkungan perairan. Survey pendahuluan bertujuan untuk melihat ada atau tidaknya karang lunak Sarcophyton sp yang akan diambil dan dijadikan sampel pengamatan pada penelitian ini.

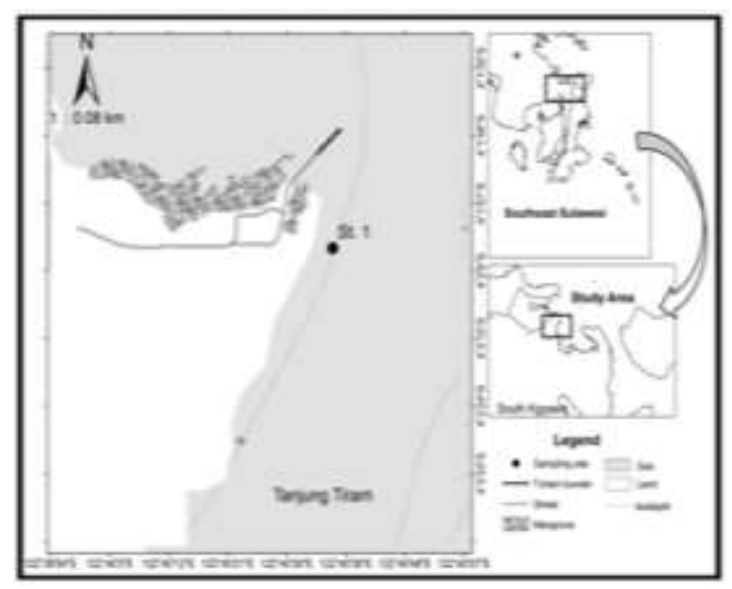

Gambar 1. Sketsa lokasi penelitian perairan Desa Tanjung Tiram.

Penentuan titik stasiun penelitian menggunakan metode purposive sampling yaitu didasarkan pada keberadaan sampel terkhusus karang sarcophyton sp. Titik stasiun penelitian Terletak di bagian selatan Perairan Desa Taanjung Tiram. Stasiun ini berada pada titik koordinat $04^{0} 02^{\prime} 15,9^{\prime}$ 'LS, dan $122^{\circ} \quad 40^{\prime}$ 23,6"BT yaitu berada diantara lamun dan 
karang dan jarak 200 meter dari ekosistem mangrove.

Pengambilan sampel karang lunak Sarcophyton sp dilakukan di stasiun1 perairan Tanjung Tiram kecamatan Moramo, Kabupaten Konawe Selatan (dapat dilihat pada gambar 5). Metode yang digunakan untuk pengambilan sampel yakni koleksi bebas (free handpicking), hal tersebut dilakukan berdasarkan keberadaan karang lunak Sarcophyton sp.

Karang lunak Sarcophyton sp dari kedalaman 3-5 meter diambil sebanyak 1500 gram atau sebanyak $10 \%$ dari koloni yang menempel pada subtrat batu dengan cara dipotong dimana proses pengambilannya dibantu dengan menggunakan alat scuba diving . Sampel tersebut kemudian di masukkan dalam dalam plastic sampel kemudian disimpan dalam cool box yang diberi es dan selanjutnya dibawa ke laboratorium.

Pengukuran parameter fisik kimia peraran dilakukan pada lokasi penelitian yakni paremeter Fisika : suhu, kecerahan perairan, TSS(Total Suspended Solid), dan arus. Parameter Kimia meliputi salinitas dan $\mathrm{pH}$

Sampel yang telah diambil dari perairan Tanjung Tiram selanjutnya dikarekterisasi panjang dan beratnya di Laboratorium Farmasi universitas Halu Oleo, untuk menganalisis senyawa bioaktif yang terkandung pada karang lunak Sarcophyton sp digunakan beberapa metode sebagai berikut.

Ekstraksi komponen bioaktif pada Sarcophyton sp. menggunakan metode modifikasi Quinn (1988) dalam Hardiningtyas (2009) dimana proses ekstraksi dilakukan secara bertingkat berdasarkan kepolaran pelarut. Pelarut yang digunakan dalam ekstraksi yaitu metanol, etil asetat, dan heksana. Perbandingan antara sampel dan masing-masing pelarut adalah 1:2 (b/v). Sampel karang lunak Sarcophyton sp. sebanyak 100 gram dipotong kecil-kecil lalu dilakukan maserasi.

Fraksinasi adalah upaya pemisahan yang dilakukan setelah mendapatkan fraksi aktif atau ekstrak aktif (Saifudin, 2014). Pemisahan dilakukan dengan cara mengambil sebagian ekstrak metanol yang kemudian ditimbang dan dilarutkan menggunakan n-heksan (fraksi nheksan) sebanyak $20 \mathrm{ml}$ dan dihomogenkan, kemudian disaring menggukan kertas saring. Filtrat yang didapatkan dilarutkan kembali menggunakan etil-asetat (fraksi etil-asetat) sebanyak $20 \mathrm{ml}$ dihomogenkan, kemudian disaring menggukan kertas saring. Filtrat terakhir yang didapatkan dilarutkan kembali menggunakan metanol (fraksi metanol ) sebanyak $20 \mathrm{ml}$ dan dihomogenkan. Pengujian ekstrak dan fraksi karang lunak Sarcophyton sp dilakukan dengn metode kromatografi lapisan tipis (KLT) dengan menggunakan pereaksi spesifik menurut Harbone (1987).

Uji aktifitas antibakteri ekstrak Sarcophyton sp. menggunakan metode cakram dimana langkah-langkah dalam pengerjaannya meliputi sterilisasi alat, pembuatan media Nutrient Agar (NA) dan media Nutrien Broth (NB) beserta sterilisasi media, persiapan kultur bakteri, peremajaan bakteri, penyiapan inokulum bakteri, penapisan aktivitas antibakteri dari ekstrak karang lunak Sarcophyton sp yang mampu menghambat pertumbuhan bakteri Escherichia coli dan Staphylococcus aureus. Sedangkan untuk fraksi partisi menggunakan metode bioautografi, dengan mengunakan bakteri uji yang sama dengan sebelumnya.

Pengamatan dan pengumpulan data dilakukan dengan menghitung nilai $\mathrm{RF}$ dan mengukur diameter zona bening atau zona hambat pada uji aktifitas antimikrob terhadap bakteri $S$. aureus dan E. colli setelah masa inkubasi selama 24 jam kemudian zona bening atau zona hambat yang terbentuk diukur menggunakan mistar. Data yang telah dikumpulkan dari hasil pengamatan dianalisa secara statistik yang diolah menggunakan softwhare komputer program Microsoft Excell 2007 dalam bentuk table dan diagram yang kemudian dideskripsikan.

\section{Hasil dan Pembahasan}

Secara umum bentuk fisik Sarcophyton sp., menyerupai jamur dengan tepi bundar atau melipat, permukaan halus seperti beludru. Warna koloni kuning, krem dan coklat. Serta Sarcophyton sp. dapat ditemukan pada rataan dengan kedalaman 2-15 meter.

Faktor yang mempengaruhi produksi senyawa metabolit sekunder pada Sarcophyton sp. yaitu kondisi lingkungan fisik habitat atau lokasi pengoleksian karang lunak Sarcophyton sp. (Hardiningtyas, 2009). Data pendukung berupa hasil analisis parameter lingkungan fisika-kimia Perairan Tanjung Tiram dapat dilihat pada Tabel 2 berikut.

Parameter fisik-kimia lingkungan perairan Tanjung Tiram diukur bersamaan dengan pengambilan sampel Sarcophyton sp. 
tepatnya pada bulan Juli 2018, dimana memasuki musim timur. Hal tersebut sesuai dengan pernyataan dari Fadika dkk, (2014) menyatakan bahwa musim Timur terjadi pada bulan Juni, Juli dan Agustus.

Tabel 2. Hasil pengukuran parameter fisikakimia perairan Tanjung Tiram

\begin{tabular}{clcc}
\hline No & $\begin{array}{c}\text { Parameter } \\
\text { lingkungan }\end{array}$ & $\begin{array}{c}\text { Hasil } \\
\text { pengukuran }\end{array}$ & $\begin{array}{c}\text { Baku } \\
\text { mutu* }\end{array}$ \\
\hline $\begin{array}{c}\text { Fisika } \\
1\end{array}$ & $\begin{array}{l}\text { Suhu }\left({ }^{\circ} \mathrm{C}\right) \\
\text { kecerahan }\end{array}$ & 32 & $28-32$ \\
2 & $\begin{array}{l}\text { (m) } \\
3\end{array}$ & 100 & $>5$ \\
$\quad \begin{array}{l}\text { kecepatan } \\
\text { arus }\end{array}$ & & \\
$\quad \begin{array}{l}\text { (m/detik) } \\
4\end{array}$ & 0,07 & - \\
TSS (mg/l) & 2,42 & 20 \\
\hline Kimia & & \\
5 & $\begin{array}{l}\text { Salinitas } \\
\text { (ppt) }\end{array}$ & 34 & $33-34$ \\
$6 \quad$ pH & 7 & $7-8,5$ \\
\hline
\end{tabular}

Keterangan : Juli 2018

Proses ekstrasi dan fraksinasi dari karang lunak Sarcophyton sp. menghasilkan ektrak berupa pasta methanol, etil-asetat dan n-heksan serta fraksi kasar dari n-heksan, Etilasetat, dan methanol dengan bobot berbeda pada tiap masing-masing ekstrak dan fraksi Sarcophyton sp.

Rendemen ekstrak menunjukkan jumlah senyawa bioaktif yang terkandung pada karang lunak Hardiningtyas (2009). Rendemen dari tiap ekstrak dan fraksi dapat dilihat pada Gambar 3.

Berdasar pada Tabel 3 dapat diketahui bahwa dari 1500 gram karang lunak Sarcophyton sp. yang diekstraksi dan fraksinasi memiliki nilai rendemen tertinggi pada ekstrak metanol dengan nilai $0,52894 \%$ yang diikuti dengan etil-asetat $(0,481473333 \%)$ dan $n-$ heksan $(0,2877 \%)$.
Nilai rendemen tertinggi pada ekstrak metanol dan nilai terendah pada ekstrak nheksan (Gambar 3 (a)), hal tersebut tersebut dikarenakan sifat dari pelarut yang digunakan bersifat polar sehingga komponen karang lunak Sarcophyton sp. yang larut dalam pelarut polar lebih besar. Saifudin (2014) berpendapat bahwa, pelarut metanol banyak gigunakan dalam proses isolasi senyawa organik bahan alam karena dapat melarutkan seluruh golongan metabolit sekunder.

Tingkatan nilai rendemen dari fraksi Sarcophyton sp. (Gambar 3 (b)), fraksi nheksan $(12,86 \%)$ memiliki persentase terendah yang kemudian diikuti oleh fraksi etil-asetat (20\%) dan fraksi metanol $(24,52 \%)$ yang memiliki nilai rendemen yang tinggi. Nilai rendemen dari fraksi sangat rendah dikarenakan poroses fraksinasi yang merupakan pemisahan yang dilakukan setelah mendapatkan ekstrak, terutama ekstrak metanol yang digunakan untuk proses fraksinasi ulangan dari laruran non polar ke larutan polar.

Nilai total rendemen dari fraksi karang lunak Sarcophyton sp. yaitu 57,38\% dimana sisanya sebanyak $42,42 \%$ merupakan kadar garam (Tabel 3). Kadar garam yang didapatkan dihasilkan dari proses fraksinasi partisi bertingkat terakhir menggunakan pelarut metanol, dan diketahui bahwa metanol merupakan jenis pelarut yang bersifat sangat polar. Kadar garam yang dihasilkan dari ekstrak metanol Sarcophyton sp. yang sangat tinggi dikarenakan sampel yang dijadikan objek penelitian merupakan organisme laut, serta saat pengambilan sampel didapatkan data parameter salinitas perairan Tanjung Tiram sebesar 34 ppt (Tabel 2). Kelarutan zat pada suatu pelarut sangat ditentukan oleh kemampuan zat tersebut membentuk ikatan hidrogen (Khopkar 2003).

Tabel 3. Rendemen Berat ekstrak pasta dan fraksi kasar lunak Sarcophyton sp.

\begin{tabular}{ccccc}
\hline \multirow{2}{*}{ Sampel } & $\begin{array}{c}\text { Berat Sampel } \\
(\mathrm{g})\end{array}$ & $\begin{array}{c}\text { Baerat Ekstrak dan } \\
\text { Fraksi }(\mathrm{g})\end{array}$ & $\begin{array}{c}\text { Rendemen Ekstrak dan } \\
\text { Fraksi }(\%)\end{array}$ \\
\hline \multirow{6}{*}{ Partisiak } & Metanol & & 7,9341 & 0,52894 \\
& Etil-asetat & 1500 & 7,2221 & 0,481473333 \\
& N-Heksan & & 4,3155 & 0,2877 \\
& N-Heksan & & 0,1286 & 12,86 \\
& Etil-asetat & \multirow{2}{*}{1} & 0,2000 & 20 \\
& Metanol & & 0,2452 & 24,52 \\
\hline
\end{tabular}




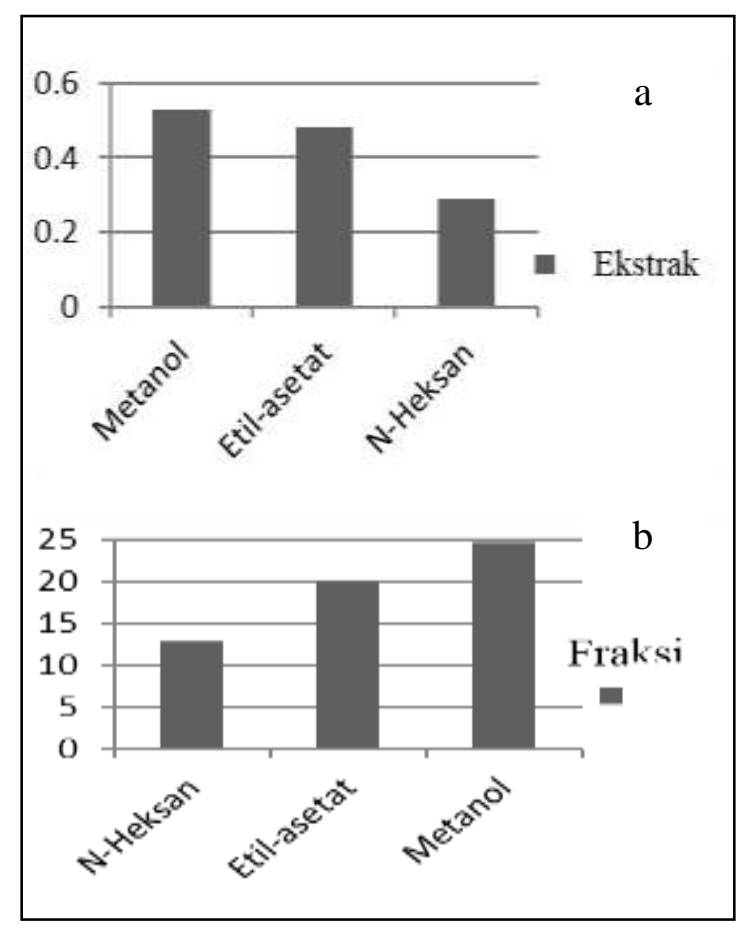

Gambar 2. (a) Rendemen ektrak Sarcophyton sp. (b) Rendemen fraksi partisi Sarcophyton sp.

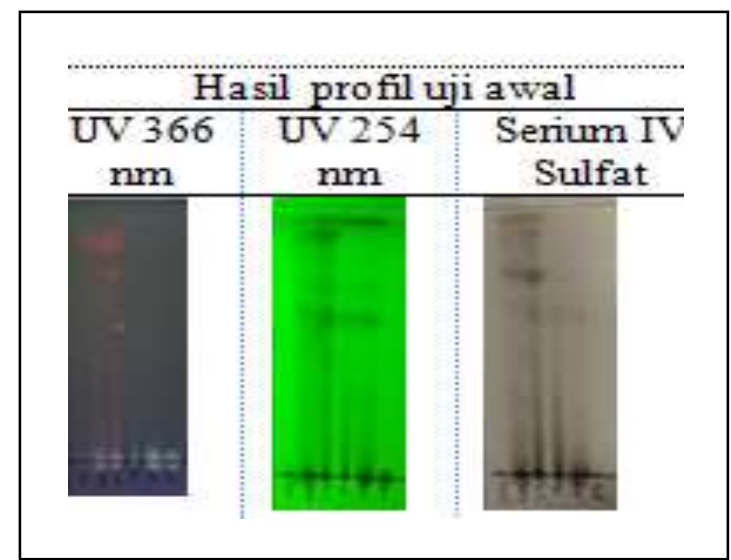

Gambar 3. Hasil Profil awal KLT ekstrak dan fraksi Sarcophyton sp.

Skrining uji awal dengan pemisahan komponen kimia ekstrak dan fraksi karang lunak Sarcophyton sp. menggunakan kromatografi kolom vakum dengan fase diam silika gel dan fase gerak campuran (elusi) nheksan : etil-asetat dengan perbandingan 7:3 $(\mathrm{v} / \mathrm{v})$. Adapun hasil skrining uji awal pada karang lunak Sarcophyton sp. dengan menggunakan larutan pereaksi dapat dilihat pada Tabel 5 berikut.

Deteksi senyawa dilakukan dengan menggunakan detector UV dibawah sinar UV $254 \mathrm{~nm}$, indicator pada plat KLT akan memancarkan warna hijau dan pada UV 366 $\mathrm{nm}$ akan memancarkan warna ungu.
Komponen yang menyerap cahaya pada 254 atau $366 \mathrm{~nm}$ akan tampak sebagai bercak gelap pada plat yang bercahaya (Gibbons, 2006).

Berdasarkan identifikasi dari profil awal KLT pada Gambar 6 menunjukkan bahwa terdapat penampakan noda berwarna merah saat terkena sinar UV $366 \mathrm{~nm}$ pada ektrak, etilasetat(B'), dan n-heksan(C'). hal tersebut dimungkinkan bahwa karang lunak Sarcophyton sp. banyak mengandung senyawa golongan terpenoid/steroid.

Penampakan noda terlihat sangat jelas ketika profil awal KLT ekstrak dan fraksi terkena sinar UV 254, terutama pada ektrak etil-asetat(B') dan n-heksan(C') serta pada partisi n-heksan(A) dan etil-asetat(B). Noda tidak tampak pada ektrak metanol(A') dan fraksi metanol(C), hal tersebut dikarenaka pada saat poses elusi pada keseluruhan ekstrak dan partisi Sarcophyton sp. menggunakan eluen nheksan : etil-asetat dengan perbandingan pelarut 7:3.

Sifat dari eluen yang menggunakan perbandingan pelarut $n$-heksan dan etil-asetat untuk mengelusi ekstrak dan partisi Sarcophyton sp. yang bersifat semi polar tidak dapat memisahkan senyawa dari ektrak metanol(A') dan partisi metanol(C) Sarcophyton sp., sehingga tidak tampak noda yang terlihat. Hal tersebut juga dijelaskan oleh Saifudin (2014) bahwa, Metanol dan asetonitril adalah pelarut organik paling polar. Heksana, benzana, dan petroleum eter bersifat non polar.

Cara yang digunakan untuk mendeteksi senyawa berfluoresensi adalah dengan dipendarkan pada sinar ultraviolet. Untuk senyawa yang tidak berfluorensi, fase diam perlu ditambah indicator fluorensi. Bercak akan kelihatan gelap dengan cara penyemprotan. Bercak kemudian dilihat dengan sinar tampak atau lampu ultraviolet. Setelah penyemprotan kadang-kadang diperlukan pemanasan (Stahl, 1985). Salahsatunya melakukan penyemprotan menggunakan serium IV sulfat terhadap fraksi ekstrak dan partisi Sarcophyton sp. sehingga menghasilkan warna ungu, biru atau kuning.

Ekstrak dan fraksi dari karang lunak Sarcophyton sp. menghasilkan 6 fraksi elusi menggunakan eluen campuran n-heksa dan etil-asetat dengan perbandingan 7:3 (Tabel 4). Nilai RF (Reterdation Faactor) ekstrak dan partisi secara berturut yakni 0,$6 ; 0,65 ; 0,7$; 0,$725 ; 0,75 ; 0,9 ; 0,95$; dan 1 . 
Tabel 4. RF Hasil skrining kimia Serium IV Sulfat ekstrak dan partisi Sarcophyton sp. menggunakan metode KLT.

\begin{tabular}{|c|c|c|}
\hline \multicolumn{2}{|c|}{$\begin{array}{c}\text { Sampel } \\
\text { Sarcophyton sp. }\end{array}$} & $\begin{array}{l}\text { RF (Reterdation Factor) } \\
\text { Serium IV Sulfat }\end{array}$ \\
\hline \multirow[t]{3}{*}{ Ekstrak } & $\begin{array}{c}\mathrm{A}^{\prime} \\
(\mathrm{MeOH})\end{array}$ & - \\
\hline & $\begin{array}{l}\mathrm{B}^{\prime}(\mathrm{EtOA} \\
\text { c) }\end{array}$ & 0,$65 ; 0,75 ; 1$ \\
\hline & $\begin{array}{l}\mathrm{C}^{\prime}(\mathrm{n}- \\
\text { hexan) }\end{array}$ & 0,$725 ; 0,9 ; 1$ \\
\hline \multirow[t]{3}{*}{ Partisi } & $\begin{array}{c}\text { A }(\mathrm{n}- \\
\text { hexan) }\end{array}$ & 0,$6 ; 0,75 ; 0,96$ \\
\hline & $\begin{array}{c}\mathrm{B} \\
(\mathrm{EtOAc})\end{array}$ & 0,$6 ; 0,75 ; 0,96$ \\
\hline & $\begin{array}{c}\mathrm{C} \\
(\mathrm{MeOH})\end{array}$ & - \\
\hline
\end{tabular}

Nilai RF tersebut (Tabel 4) menunjukkan bahwa ekstrak dan partisi dari Sarcophyton sp. diantaranya mengandung testoteron dan kolestrol, hal tersebut sesuai dengan pernyataan dari Alwir (2001) yang menyatakan bahwa, kandungan testoteron dan kolestrol dapat diketahui dengan RF secara berurutan 0,9 dan 0,96 .

Hasil skrining plat KLT (Kromatografi Lapis Tipis) ditemukan tiga jenis senyawa yaitu alkaloid, terpenoid dan flafanoid dengan menggunakan eluen n-heksan dan etil-asetat (7:3) dimana pereaksi mayer, wagner dan dragendroff untuk alkaloid, pereaksi lieberman-buchard untuk terpenoid serta besi III klorida untuk flafanoid disajikan pada Gambar 4. Senyawa alkaloid ditandai dengan terbentuknya noda yang berwarna hijaukuning untuk pereaksi alkaloid-mayer RF 0,9625 , coklat-kuning untuk pereaksi wagneralkaloid pada RF 0,975 dan hijau-kuning untuk pereaksi dragendroff-alkaloid RF 0,9625 yang ditemukan pada ektrak Sarcophyton $s p$. etil-asetat(B') dan nheksan(C') (Gambar 4 dan Tabel 5) .

Senyawa alkaloid pada karang lunak Sarcophyton sp. ditandai dengan adanya lendir yang dikeluarkan setelah dilakukan pemotongan ketika akan dimaserasi. Hal ini sesuai dengan pendapat dari Hardiningtyas (2009) yang menyatakan bahwa, senyawa alkaloid digunakan oleh biota laut sebagai pertahanan diri dan pencegahan infeksi. Sadarun $d k k$, (2008) menerangkan bahwa, sifat yang menonjol dari ekosistem terumbu karang adalah keanekaragamannya yang tinggi, jumlah spesies yang banyak, dan bentuk morfologinya yang bervariasi. Berdasarkan hal tersebut, Intiyani (2014) menegaskan bahwa, dengan keanekaragaman biota yang tinggi, jumlah spesiesnya yang banyak dan bentuk morfologinya yang berfariasi, membuat kompetisi spasial yang ada semakin tinggi pula.

Identifikasi senyawa terpenoid dari karang lunak Sarcophyton sp. ditandai dengan terbentuknya noda berwarna ungu tua kebiruan pada ekstrak ekstrak etilasetat(B') dan n-heksan(C') serta pada partisi n-heksan(A) dan etil-asetat(B) (dapat dilihat pada Gambar 6) dengan nilai RF 1; 0,$9 ; 0,85 ; 0,8$; dan 0,7 (disajikan pada tabel 5). Steroid/triterpenoid merupakan golongan senyawa triterpenoid. Hal tersebut juga sesuai dengan hasil penelitian yang dilakukan oleh Badria et al. (1998) dan Swant et al. (2006) yang menunjukkan bahwa karang lunak Sarcophyton sp. banyak mengandung senyawabioakif steroid dan terpenoid. Senyawa kimia aktif tersebut menunjukkan aktivitas anti bakteri, antifungi, antitumor, neurotoksik, dan antiinflamantori.

Saifudin (2014) berpendapat bahwa, terdapat dua jalur biosintesis pembentuk terpenoid makhluk hidup ada dua, yakni jalur mevalonat dan deoksiselulosa. Jalur biosintesis deoksiselulosa adalah jalur biosintesis yang baru ditemukan. Jalur deoksiselulosa lazim ada di dalam tumbuhan atau mikroba namun jarang terdapat di dalam makhluk vertebrata termasuk manusia. Berdasarkan hal tersebut, bahwa karang lunak Sarcophyton sp. dapat melakukan biosintesis dengan jalur deoksiselulosa yakni dengan cara simbiosis mutualisme dengan zooxanthellae yang berfotosintesis untuk memenuhi kebutuhan makananya.

Hal tersebut juga diperkuat oleh Castro P \& Huber ME (2005) yang berpendapat bahwa beberapa terumbu karang membutuhkan cahaya matahari untuk melakukan kegiatan fotosintesis. Polip-polip penyusun terumbu karang yang terletak pada bagian atas terumbu karang dapat menangkap makanan yang terbawa arus laut dan juga melakukan fotosintesis. Oleh karena itu, oksigen hasil fotosintesis yang terlarut dalam air dapat dimanfaatkan oleh spesies laut lainnya. Hewan karang sebagai pembangun utama terumbu adalah organisme laut yang efisien karena mampu tumbuh subur dalam lingkungan sedikit nutrien (oligotrofik). 


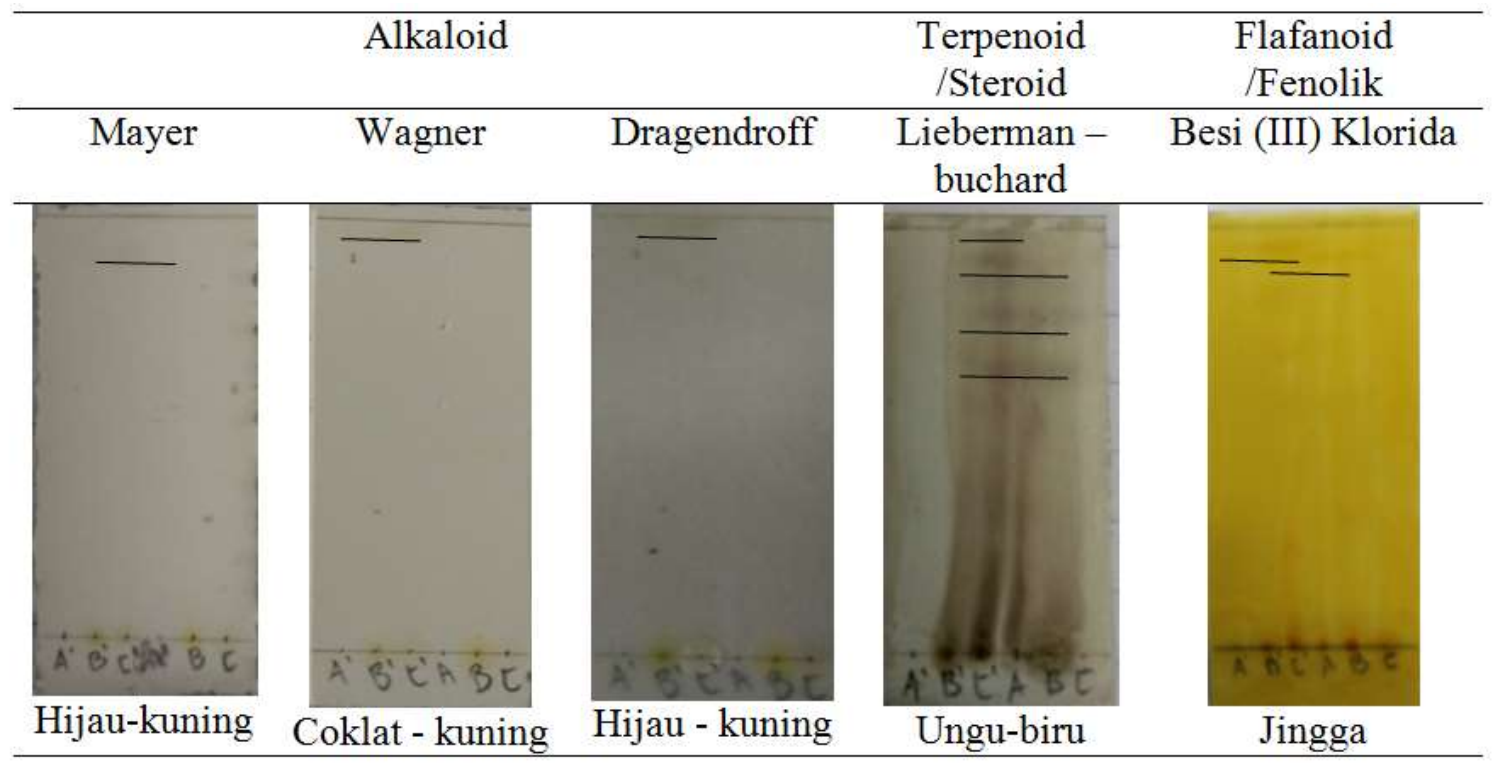

Gambar 4. Hasil skrining plat KLT ekstrak dan partisi Sarcophyton sp. menggunakan pereaksi spesifik menurut Harbone (1987).

Tabel 5. RF Hasil skrining kimia uji metabolit sekunder ekstrak dan fraksi Sarcophyton sp. menggunakan metode KLT (Kromatografi Lapis Tipis).

\begin{tabular}{|c|c|c|c|c|c|c|}
\hline \multirow{2}{*}{\multicolumn{2}{|c|}{$\begin{array}{c}\text { Sampel } \\
\text { Sarcophyton } \mathrm{sp} .\end{array}$}} & \multicolumn{5}{|c|}{ RF (Reterdation Factor) } \\
\hline & & \multicolumn{3}{|c|}{ Alkaloid } & \multirow{2}{*}{$\begin{array}{c}\text { Steroid/ } \\
\text { Terpenoid } \\
\text { Lieberman- } \\
\text { Buchard } \\
\end{array}$} & \multirow{2}{*}{$\begin{array}{c}\text { Fenolik/ } \\
\text { Flaafanoid } \\
\text { Besi III } \\
\text { Klorida } \\
\end{array}$} \\
\hline & & Mayer & $\begin{array}{c}\text { Wagne } \\
\mathrm{r}\end{array}$ & $\begin{array}{l}\text { Dragendrof } \\
\mathrm{f}\end{array}$ & & \\
\hline \multirow[t]{3}{*}{ Ekstrak } & $\begin{array}{c}\mathrm{A}^{\prime} \\
(\mathrm{MeOH})\end{array}$ & - & - & - & - & 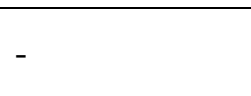 \\
\hline & $\begin{array}{c}\mathrm{B}^{\prime} \\
\left(\mathrm{EtOAc}^{\prime}\right)\end{array}$ & 0,9625 & 0,975 & 0,9625 & $\begin{array}{l}1 ; 0,9 ; 0,85 \\
0,8 ; 0,7\end{array}$ & 0,$96 ; 0,8 ; 0,7$ \\
\hline & $\begin{array}{c}C^{\prime} \\
\text { (n-hexan) }\end{array}$ & 0,9625 & 0,975 & 0,9625 & $\begin{array}{l}1 ; 0,9 ; 0,85 \\
0,8 ; 0,7\end{array}$ & 0,$96 ; 0,8 ; 0,7$ \\
\hline \multirow{3}{*}{ Fraksi } & $\begin{array}{c}\text { A } \\
\text { (n-hexan) }\end{array}$ & - & - & - & 0,$85 ; 0,7$ & 0,$85 ; 0,7$ \\
\hline & $\begin{array}{c}\mathrm{B} \\
(\mathrm{EtOAc})\end{array}$ & - & - & - & 0,$85 ; 0,7$ & 0,$85 ; 0,7$ \\
\hline & $\begin{array}{c}\mathrm{C} \\
(\mathrm{MeOH})\end{array}$ & - & - & - & - & - \\
\hline
\end{tabular}

Aktivitas Anti Bakteri Ekstrak dan Fraksi

Partisi Sarcophyton sp.

Ekstrak n-heksan karang lunak Sarcophyton sp. memiliki aktivitas antibakteri terhadap $S$. aureus yang paling aktif dengan diameter penghambatan terbesar dibandingkan ekstrak lainnya (Gambar 6s). Menurut Sahidin (2018) komponen zona hambat dan control positif dikategorikan kuat (10-20 mm), sedang (5$10 \mathrm{~mm})$ dan lemah $(<5 \mathrm{~mm})$.

Konsentrasi ekstrak tertinggi dan tergolong kuat dengan nilai 1000 ppm serta memiliki diameter zona hambat lebih dari
$10 \mathrm{~mm}$. Secara berurutan kemudian diikuti konsentrasi 500 dan 250 ppm yang tergolong sedang dengan diameter zona hambat lebih dari $5 \mathrm{~mm}$, serta pada konsentrasi $125 \mathrm{ppm}$ yang tergolong rendah memiliki diameter zonahambat kurang dari $5 \mathrm{~mm}$. Dari hasil ekstrak Sarcophyton sp. dengan pelrut nheksan yang dimasserasi secara bertingkat dapat digolongkan kedalam golongan senyawa anti bakteri yang memiliki diameter zona daya hambat yang berbeda pada tiap konsentrasinya. Hal ini diduga karena jika semakin konsentrasi ekstrak Sarcophyton sp. dengan pelrut $\mathrm{n}$-heksan yang digunakan, 
maka semakin tertinggi dan tergolong menunjukkan aktifitas antibakteri.

Aktivitas antibakteri dari ekstrak etil asetat tergolong sedang dengan nilai 250 ppm serta memiliki diameter zona hambat lebih dari $5 \mathrm{~mm}$. Parhusip (2006) mengemukakan bahwa, etil-asetat merupakan pelarut semi polar yang memiliki dua sifat kelarutan,yaitu hidrofilik dan lipofilik. Estrak metanol karang lunak Sarcophyton sp. tidak memiliki aktivitas antibakteri terhadap $S$. aureus. Serupa dengan pengamatan yang telah dilakukan oleh Hardiningtyas (2009) dalam penelitiannya bahwa hasil pengamatan ekstrak metanol menunjukkan aktivitas antibakteri dengan diameter penghambatan yang lebih rendah. Hal ini diduga senyawa bioaktif yang terdapat pada ekstrak metanol karang lunak Sarcophyton sp. hanya bersifat polar serta rendahnya komponen senyawa sebagai antibakteri yang terlarut, sehingga keefektifan menghambat bakteri $S$. aureus. lebih rendah dibandingkan dengan ekstrak etil-asetat maupun n-heksan. Harbone (1987) memperkuat penjelasan di atas, bahwa pelarut metanol mampu mengekstrak alkaloid kuartenerdan komponen fenolik lainnya.

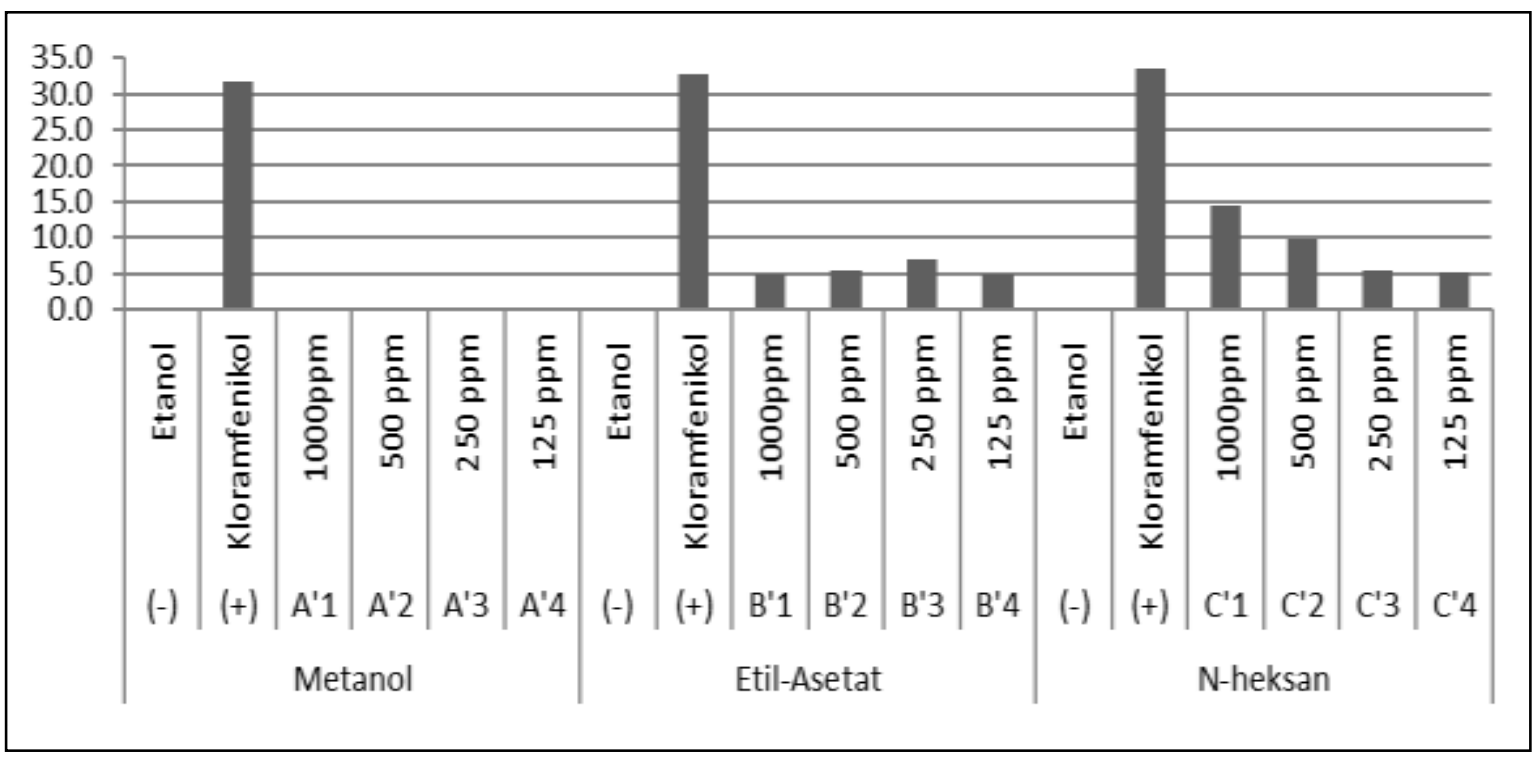

Gambar 5. Aktifitas antibakteri ekstrak metanol, etil-asetat dan n-heksan Sarcophyton sp. beserta kontrol positif terhadap bakteri uji (S. aureus).

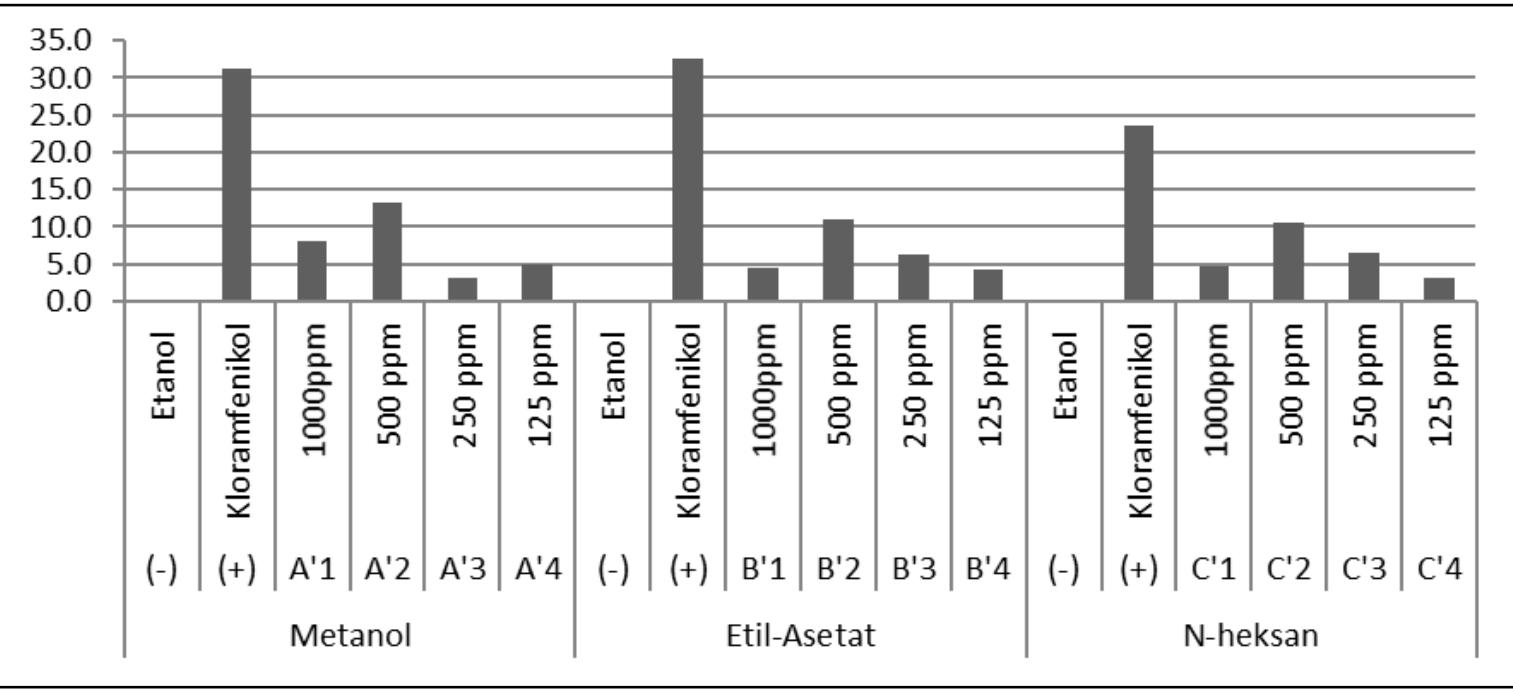

Gambar 6. Aktifitas antibakteri ekstrak metanol, etil-asetat dan n-heksan Sarcophyton sp. beserta control positif terhadap bakteri uji (E. coli). 
Tabel 6. Hasil uji KLT bioautografi Sarcophyton sp. terhadap bakteri S. aureus dan E.coli.

\begin{tabular}{ccccc}
\hline No. & Partisi & Kode & Bakteri & Keterangan \\
\hline 1 & N-heksan & A & & $(++)$ \\
2 & Etil-asetat & B & S. aureus & $(+)$ \\
3 & Metanol & C & & $(-)$ \\
\hline 4 & N-heksan & A & & $(+++)$ \\
5 & Etil-asetat & B & E.coli & $(++)$ \\
6 & Metanol & C & & $(-)$ \\
\hline
\end{tabular}

Keterangan : * (+++) sangat kuat; (++) kuat; (+) sedang; (-) lemah

Perbedaan kesensitifan bakteri gram positif dan gram negatif berkaitan dengan struktur dalam dinding selnya, seperti jumlah peptidoglikan (adanya reseptor, pori-pori, dan lipid), sifat ikatan silang, dan aktivitas enzim autolitik. Komponen tersebut merupakan faktor yang menentukan penetrasi, pengikatan, dan aktivitas senyawa antimikroba (Jawet 1998). Branen dan Davidson (1993) memperkuat penjelasan yang menerangkan bahwa, ketahanan bakteri gram negatif dan gram positif terhadap senyawa antibakteri berbeda-beda. Bakteri gram negatif umumnya sensitif terhadap senyawa antimikroba yang bersifat polar, sedangkan bakeri gram positif lebih sensitif terhadap senyawa antibakteri yang bersifat non polar.

Kontrol positif kloramfenkol (Gambar 5 dan Gambar 6) diketahui dapat menghambat keseluruhan bakteri uji (S. aureus dan E.coli) dengan diameter zona hambar lebih besar dari pada keseluruhan ekstrak karang lunak Sarcophyton sp. Jawetz et al. (1996) menerangkan bahwa, kloramfenikol merupakan senyawa antibakteri yang sangat stabil dan berdifusi dengan baik dalam pembenihan agar. Faktor-faktor yang mempengaruhi aktivitas antimikroba adalah $\mathrm{pH}$ lingkungan, komposisi media, stabilitas senyawa antimikroba, besarnya inokulum, lamanya inkubasi, dan aktivitas metabolik mikroorganisme.

Hasil dari KLT bioautografi fraksi partisi n-heksan karang lunak Sarcophyton sp. tergolong kuat dibandingkan dengan fraksi etil-asetat maupun metanolterhadap bakteri uji S. aureus dan E.coli (Tabel 6). Hal ini diduga mayoritas metabolit sekunder bersifat semi polar sehingga larut dalam pelarut organik. Metanol dan asetonitril adalah pelarut organik paling polar. Heksana, benzana, dan petroleum eter bersifat non polar.

Hanya sebagian saja dari metabolit sekunder bersifat polar dan larut dalam metanol atau air. Kebanyakan metabolit yang larut metanol adalah senyawa glikosida yang mengikat satu atau lebih molekul gula heksosa/pentosa. Adapun kebanyakan golongan terpenoid bersifat non polar sehingga larut ke dalam pelarut non polar dan semi polar. Namun untuk monoterpen dan seskuiterpen masih mampu larut dalam metanol (Saifudin, 2014).

Karang lunak Sarcophyton sp. pada perairan Tanjung Tiram hidup secara alami dan tersebar luas di kedalaman 2-8 meter. Karang lunak ini hidup berdampingan dengan karang lunak atau organism lainnya dan berperan sebagai penyusun ekosistem terumbu karang. Halini sesuai dengan pendapat dari Sadarun, (2008) menerangkan bahwa sifat yang menonjol dari ekosistem terumbu karang adalah keanekaragamannya yang tinggi, jumlah spesies yang banyak, dan bentuk morfologinya yang bervariasi.

Keanekaragaman, jumlah spesies yang tinggi serta bentuk morfologi ini lah yang memicu terjadinya kompetisi ruang dan makanan dengan tingkat yang lebih tinggi. Hal ini memicu karang lunak Sarcophyton sp. untuk memproduksi metabolit sekunder. Hasil penelitian Fleury et al. (2000) memperkuat teroi dengan mejelaskan bahwa, produksi senyawa bioaktif sarcophytoxide dari karang lunak Sarcophyton ehrenbergi semakin meningkat ketika didekatkan dengan karang Pacillopora darmicornis.

Menurut Triyulianti (2009), seiring bertambahnya kedalaman secara eksponensial menyebabkan berkurangnya intensitas cahaya. Berdasarkan hasil penelitian yang dilakukan 
oleh Tursch et al. (1978) diketahui bahwa hanya karang lunak yang bersimbiosis dengan zooxanthellae yang dapat menghasilkan senyawa terpen. Jenis- jenis hewan yang kurang atau tidak mengandung alga ini tidak dapat menghasilkan senyawa terpen. Contohnya adalah senyawa eunicellin ditemukan pada jenis gorgonia Eunicella stricta, tetapi tidak ditemukan pada jenis gorgonia E. stricta yang hidup di laut dalam. Hal ini disebabkan intensitas sinar matahari yang diperlukan zooxanthellae untuk fotosintesis sangat rendah.

\section{Simpulan}

1. Ekstrak dan fraksi partisi dari karang lunak Sarcophyton sp. yang diambil dari perairan Tanjung Tiram teridentifikasi senyawa bioaktif alkaloid, steroid/ terpenoid, Flavanoid/venolik.

2. Ekatrak dan fraksi partisi dari karang lunak Sarcophyton sp. yang paling tinggi kandungan metabolit sekundernya yaitu pada ektrak etil-asetat dan ektrak n-heksan dari karang lunak Sarcophyton sp. dengan nilai RF 1 untuk steroid/terpenoid, RF 0,96 untuk fenolik/ flafanoid, dan 0,9625 untuk alkaloid.

3. Aktivitas daya hambat ektrak dan fraksi partisi n-heksan karang lunak Sarcophyton sp. berpotensi sebagai antibakteri aktif terhadap bakteri $S$. aureus dan E. coli dengan respon zona hambat yang kuat dengan menggunakan medote cakram maupun metode bioautografi.

\section{Daftar Pustaka}

Alwir, Y. 2001. Isolasi,penentuan komposisi kimia dan uji biologi Steroid dari cacing laut, Eunice siciliencis. Program studi Biotekhnologi [Tesis]. Bogor: program Pasca Sarjana Institut Pertanian Bogor.

Badria FA, Guirguis AN, Perovic S, Steffen R, Muller WEG, Schroder HC. 1998. Sarcophytolide: a new neuroprotective compound from soft coral Sarcophyton glaucum. Toxicology 131(3):133-143.

Branen AL, Davidson PJ. 1993. Antimicrobial in Foods. New York : Marcel Dekker.

Castro P \& Huber ME. 2005. Marine Biology Ed ke-5. New York: Mc Graw Hill International.Page 119-125.

Fadika, U., Rifai, A, Rochaddi. 2014. Arah Dan Kecepatan Angin Musiman Serta Kaitannya Dengan Sebaran Suhu
Permukaan Laut Di Selatan

Pangandaran Jawa Barat. Jurnal Oseanografi. 3 (3) :429-237.

Fleury BGJ, Coll E, Duquesne S, Figueiredo L. 2000. Effect of nutrient enrichment on the complementary (secondary) metabolite composition of the soft coral Sarcophyton ehrenbergi (Cnidaria:Octocoralia: Alcyonaceae) of the Great Barrier Reef. Mar. Biol 136:63-68

Gibbons, S. 2006. An Intoduction to Planar Chromatography. Humana Press. Totowa New Jersey.

Greenwood D. 1995. Bacillus. Di dalam: Greenwood D, Slack RCB, Peutherer JF, editor. Medical Microbiology. Ed ke4. Hongkong : ELBS.

Harborne JB. 1987. Metode Fitokimia. Padmawinata K, Soediro I, penerjemah. Bandung: ITB. Terjemahan dari: Phytochemical Methods.

Hardiningtyas D, S. 2009. Aktivitas Antibakteri Ekstrak Karang Lunak sarcophytonn sp. yang difrakmentasi dan tidak difrakmentasi di Perairan Pulau Pramuka Kepulauan Seribu (Skripsi). Fakultas Perikanan dan Ilmu Kelautan. Institut Pertanian Bogor.

Intiyani M, WO. 2014. Kajian Potensi Aktivitas Antibakteri dan Metabolit Sekunder Beberapa Jenis Spons (SKRIPSI). Program Manajemen Sumber Daya Perairan.Fakultas Perikanan dan Ilmu Kelautan. Universitas Halu Oleo.

Jawet E. 1998. Obat-obat kemoteuratika. Di dalam: Katzung BG, editor. Staf Dosen Farmakologi Fakultas Kedokteran UNSRI, penerjemah. Farmakologi Dasar dan Klinik. Jakarta: ECG. Terjemahan dari: Basic and Clinical Pharmacology.

Jawetz E, Melnick J, Adelberg E. 1996. Mikrobiologi Kedokteran. Ed ke-20. Nugroho E, Maulany RF, penerjemah. Jakarta: EGC. Terjemahan dari: Medical Microbiology.

Khopkar SM. 2003. Konsep Dasar Kimia Analitik. Jakarta: UI-Press.

Parhusip A JN. 2006. Kajian mekanisme antibakteri ekstrak andaliman (Zanthoxylum acanthopodium DC) terhadap bakteri pathogen pangan 
[disertasi]. Bogor: Sekolah Pasca Sarjana, Institut Pertanian Bogor.

Quinn RJ. 1988. Chemistry of Aqueous Marine Extracts: isolation Techniques in BioorganicMarine Chemistry, Vol. 2. Verlag Berlin Heidelberg: Springer.

Robinson T. 1995. Kandungan Organik Tumbuhan Tinggi. Bandung: ITB Press.

Sadarun, B. 2008. Petunjuk Pelaksanaan Transplantasi Karang. Direktorat Konservasi dan Taman Nasional Laut. Direktorat Jendral Kelautan, Pesisirvdan Pulau-Pulau Kecil. Departement Kelautan dan Perikanan. Jakarta. 36 hal.

Sahidin, I. 2012. Mengenal Senyawa Alami. Unhalu Press. Kendari.

Sahidin, I.,Sabandar C, W., Wahyuni., Hamsidi R., Malaka H M., Sadarun B., Aslan L O. 2018. A-nor Steroids from the Marine Sponge, Clathria Species. Malaysian Journal of Analytical Sciences. 22 (3): 375 - 382.

Saifudin A. 2014. Senyawa Alam Metabolit Sekunder (Teori, Konsep, dan Teknik Pemurnian). Deepublish. (7):54. ISBN 978-602-280-472-7.

Sammarco PW, Coll JC. Chemical adaptations in the Octocorallia: evolutionary considerations. MarEcol Prog Ser. 1992.88:93-104.

Sawant S, Youssef D, Mayer A, Sylvester P, Wall V, Arant M, El-Sayed K. 2006. Anticancer and anti-inflamantory sulphur-containing semisynthetic derivatives of sarcophine. Chem. Pharm. Bull. 54(8):1119-1123.

Sinaga E L R, Muhtadi A, Bakti D. 2016. Profil Suhu, Oksigen Terlarut, dan $\mathrm{pH}$ Secara Vertikal Selama 24 Jam di Danau Kelapa Gading Kabupaten Asahan Sumatera Utara. Omni-Akuatika 12(2): 114-124.

Triyulianti I. 2009. Bioaktivitas ekstrak karang lunak Sinularia sp. dan Lobophytum sp. hasil fragmentasi di Perairan Pulau Pramuka, Kepulauan Seribu, DKI Jakarta [tesis]. Bogor: Sekoah Pasca Sarjana, Institut Pertanian Bogor.

Tursch B, Braekman CJ, Dalose D, Kasin M. 1978. Terpenoid from oelenterata. Di dalam: Scheuuer PJ, editor. Marine Natural Products. New York: Chemical and Biological Perspecteus II Academic Press 